\title{
Serial Integration, Real Innovation: Roles of Diverse Knowledge and Communicative Participation in Crowdsourcing
}

\author{
Yao Sun \\ College of Arts and Sciences \\ University of South Florida \\ yaosun@usf.edu
}

\author{
Ann Majchrzak \\ Marshall School of Business \\ University of Southern California \\ majchrza@usc.edu
}

\author{
Arvind Malhotra \\ Kenan-Flagler Business School \\ University of North Carolina at \\ Chapel Hill \\ arvind_malhotra@kenan- \\ flagler.unc.edu
}

\begin{abstract}
Despite a burgeoning public and scholarly interest on open innovation and crowdsourcing, how to enable members of online temporary crowd to maintain knowledge integration and innovation remains underexplored. This study seeks to understand the ways in which online crowd members collectively generate more innovative and serial integrative solutions to crowdsourced open innovation challenges. Analyzing 3,200 unique posts generated by 486 participants of 21 organization-sponsored online crowdsourcing innovation challenges, this research demonstrates that crowd members contribute more innovative solutions when being exposed to explicitly shared diverse knowledge, and that crowd members' communicative participation acts as a catalyst for the production of both innovation and serial knowledge integration. Findings suggest that managers who seek to generate knowledge integration and innovation should endeavor to implement systems that afford highlevel communicative participation, as well as encourage crowd members to make their diverse knowledge explicit while minimizing their cognitive load in knowledge sharing.
\end{abstract}

\section{Introduction}

Innovation is increasingly generated by harnessing the wisdom of crowds [1-3]. Although organizations have been particularly successful using outsourcing to find answers to problems that are clearly defined or can be modularized into sub-problems for crowd members to solve independently [4], more and more innovation challenges that current business practitioners are faced with require solving broadly defined problems characterized by interdependent and nondecomposable elements and, therefore, may be better solved by integrating collaborators' diverse perspectives [5-7]. With the Internet enabling worldwide collaborative interactions, crowdsourcing allows firms to make a faster move when facing a rapidly changing business environment.

Knowledge collaboration lays the foundation for successful crowdsourced open innovation [6, 8]. Crowdsourcing promotes innovation through allowing the amalgamation of diverse perspectives, knowledge, skills and expertise [9]. According to Howe [10], such a new pattern of innovation is essentially a manifestation of how "everyday people use their spare cycles to create content, solve problems, even do corporate R\&D" (p.1). Brabham [11], further, suggested that "the crowd's strength lies in its composite or aggregate of ideas, rather than in a collaboration of ideas... this 'wisdom of crowds' is derived not from averaging solutions, but from aggregating them" (p. 1125).

Examining the dynamic of how online crowd collectively maintains the integration of shared knowledge and the production of innovative solutions, this research seeks to understand the conditions under which members of temporary online crowd collaboratively produce innovative and serial integrative solutions in response to open innovation challenges. Informed by theoretical frameworks of crowdsourcing and open innovation, this study asks the following research question: What is the mechanism underlying crowdsourcing participants' production of innovative and serial integrative knowledge contribution? Particularly, this study looks at the impacts of online crowd members' communicative participation and shared diverse knowledge that allow the crowd to perceive the challenge from multiple perspectives and thus generate innovation. Moreover, the present study attempts to identify factors that can improve participants' continuous and serial contribution of knowledge integration. In addition to being of theoretical interest, this research also has 
practical relevance to managerial practice of generating innovation through crowd-powered knowledge collaboration.

\section{Theoretical Framework}

\subsection{Crowdsourcing for Innovation and Knowledge Integration}

Crowd-powered open innovation is gaining attention in a wide variety of fields $[12,13]$. Such a revolution in business model and management strategy reflects the evolution supported by emerging information technology and the corresponding advancement of computer-mediated interaction. Open innovation, by definition, is to open up the innovation process. Chesbrough [1] defined it as "the use of purposive inflows and outflows of knowledge to accelerate internal innovation, and to expand the markets for external use of innovation" (p.1). The growth of open innovation is deeply rooted in the theoretical and practical developments taking place over the decade $[14,15]$, focusing on better utilizing external crowd-generated resources to improve internal innovation.

Fueled by the wisdom of crowds, open innovation is contrary to closed innovation which means companies rely on a small group of experts to develop creative ideas internally [12]. Open innovation is catalyzed by socioeconomic changes such as the rapid advancement of information technology, improved labor division, as well as the expanding globalization [16]. Going hand in hand are trends such as outsourcing which makes companies more agile and flexible [17]. Instead of reflecting a dichotomy, open innovation is better to be described as a continuum which includes various degrees and forms of innovation [16]. It is a multifaceted and multidimensional notion consisting of activities such as inbound innovation, outbound innovation, or a compound mix of various types of innovation [16, 18].

Innovation research has highlighted the value of knowledge integration [19-23], which refers to "the synthesis of individuals' specialized knowledge into situation-specific systemic knowledge" [24, p. 1030]. This study, in particular, defines serial integration as a series of integrative knowledge contributed by a same individual member of the online temporary crowd. Compared to knowledge transfer which is timeconsuming and inefficient [25,26], knowledge integration relies on the transcending approach beyond knowledge transfer and offers a synergistic amalgamation of the "nature of the dialogue" [27, p.14]. However, knowledge integration among the members of online temporary crowd is often difficult to accomplish, because online crowd is systematically different from small-scale groups in which the members share existing social connections and thus can easily build mutual understandings [9, 28, 29]. In this regard, the success of a crowd-powered innovation challenge is contingent upon the degree to which members of the crowd maintain knowledge integration and innovation via collaborative knowledge sharing.

\subsection{Role of Diverse Knowledge in Crowdsourcing for Innovation}

The value of knowledge diversity lays the theoretical foundation for collective innovation. Compared to internal R\&D groups, external crowds possess more diverse knowledge, and thus are likely to contribute ideas in greater quantity and higher quality [30-33]. As innovation research demonstrated, a crowd of independent strangers with diverse knowledge can be more capable of generating innovative ideas compared to a small number of internal experts with similar knowledge backgrounds [9,34-36], and the wide range of knowledge domains manifested by crowd-generated posts in online open challenges can boost the emergence of creative solutions [20,34,3739]. Studies have also demonstrated the important role played by transferrable knowledge components in large-scale creative problem solving. For example, to collectively generate innovative solutions, collaborators often brainstorm and share a variety of short concise statements about personal experience, facts, and objectives [40]. Cronin and Weingart [41] suggested that sharing understandable and transferrable components such as assumptions and aims is critical for collective creativity, as the exposure to these knowledge configurations enables collaborators to align their efforts and make sure that they are working toward a common goal.

Voicing a broad range of knowledge elements such as potential ideas, questions and problem definitions can provide a fertile ground for crowdsourcing participants to develop integrative solutions that consolidate and align diverse knowledge. Research suggests that these fragments do not have to be transformed into a common knowledge; instead the fragments can emerge into a provisional collage of loosely coupled knowledge components [42]. Within the community of game developers, for example, the integrative vision of user experience improved when collaborators successfully developed a collage of fragmentary representations of users' feedback [43]. Taken together: 
H1: In online crowdsourcing, crowd members' knowledge diversity will increase the amount of innovation that they contribute.

H2: In online crowdsourcing, crowd members' knowledge diversity will increase the likelihood that they contribute serial knowledge integration.

\subsection{Role of Communicative Participation in Crowdsourcing for Innovation}

As social media lends itself to knowledge collaboration and idea generation, members of the crowd can make their voices heard through participatory online communication $[44,45]$. Collaboratively producing innovative solutions, online crowd members need to have conversations to reuse one another's existing knowledge and co-create new common knowledge [46,47]. Since the knowledge transferred and exchanged in collaborative work is often tacit and incompletely coded [48], making sense of such knowledge requires collaborators to maintain a high-level communicative participation. Therefore, to study innovation and knowledge integration, researchers must take into account the communication processes and practices that crowd members undertake when they share and co-create knowledge [49].

Individuals become more creative when they are involved in communicative knowledge collaboration. Collective innovation emerges from active interaction during which existing ideas are revisited and recombined to produce creative solutions [50-52]. Research on creativity has shown positive relationships between individual creativity and contextual factors such as communicating styles [53,54], indicating that creative output at the individual level is nested in the collective interaction that "constituted the social context in which the creative behavior occurs" [55, p.303]. In online ideation communities, specifically, participants who engage in communicative activities such as posting, commenting and voting can contribute more implementable ideas because they have experienced many cognitive iterations during this process [56].

Communicative participation boosts knowledge integration and synthesis, as it affords the opportunity to re-consider previous knowledge and its connection with the current problem. Group technologies such as face-to-face group supporting systems were found to enhance knowledge co-creation because they improve the quality of the interactions among collaborators [57]. In online knowledge collaboration communities, crowd members are able to construct a common integrative understanding of the problem after engaging in a communicative sharing process $[6,58]$. Therefore, this study poses:

H3: In online crowdsourcing, crowd members' communicative participation will increase the amount of innovation that they contribute.

H4: In online crowdsourcing, crowd members' communicative participation will increase the likelihood that they contribute serial knowledge integration.

\section{Method}

\subsection{Data Collection}

Collaborating with 21 university-partnered companies, this study harvested data from the companies' crowdsourcing innovation challenges. Within a period of 7-10 days, the companies employed a virtual platform to announce open calls and seek for crowds' responses to the companies' broadly-defined strategic problems. For example, a fashion media company posed a challenge asking how the company could strategically use mobile technology to maintain current customers as well as attract new ones; members of the online crowd were then encouraged to anonymously contribute their thoughts through posting, viewing and voting. Each company evaluated the innovativeness of the posts and provided incentives for the top solutions generated during the innovation challenge.

Upon completion, independent coders were hired and trained to code all the posts (intercoder reliability $\kappa$ $=0.74, p<0.001) . \mathrm{A}$ total of 486 participants collectively generated 3,200 posts, of which 242 posts were identified as integrative solutions that explicitly synthesized prior shared knowledge while proposing a way of solving the problem. In addition, after removing irrelevant posts, six non-solution types of knowledge contribution were identified (Table 1).

Table 1. A Summary of Non-Solution Types of Knowledge Contribution

\begin{tabular}{lll}
\hline $\begin{array}{l}\text { Knowledge } \\
\text { Type }\end{array}$ & Illustration & $\begin{array}{l}\text { Number } \\
\text { of Posts }\end{array}$ \\
\hline Idea & $\begin{array}{l}\text { Posts demonstrating loosely- } \\
\text { structured thoughts. }\end{array}$ & 1182 \\
Tradeoff & $\begin{array}{l}\text { Posts describing conflicting } \\
\text { situations. }\end{array}$ & 199 \\
Example & $\begin{array}{l}\text { Posts describing real-life } \\
\text { cases. }\end{array}$ & 208 \\
Fact & $\begin{array}{l}\text { Posts presenting objective } \\
\text { statements or statistics. }\end{array}$ & 332 \\
Question & Posts raising questions or & 418 \\
\hline
\end{tabular}




\begin{tabular}{ll}
\hline \multirow{2}{*}{ Agreement } & $\begin{array}{l}\text { concerns. } \\
\text { Posts explicitly showing } \\
\text { agreement or support. }\end{array}$ \\
\hline
\end{tabular}

\subsection{Measures}

3.2.1. Dependent Variables. One dependent variable, amount of innovation, is operationalized by calculating each crowd member's total number of contributed integrative solutions that were considered innovative by the sponsoring companies $(\mathrm{M}=4.98$, $\mathrm{SD}=5.62)$. The other dependent variable is serial knowledge integration $(\mathrm{M}=0.39, \mathrm{SD}=0.49)$, coded by observing an integrative solution's serial position among the focal contributor's all contributed integrative solutions. Accordingly, a contributor's very first integration was coded as 1 and subsequent integrations as 2, and all the other non-integrative posts were coded as 0 .

Table 2. Descriptive Statistics and Zero-order Correlations (Amount of Innovation)

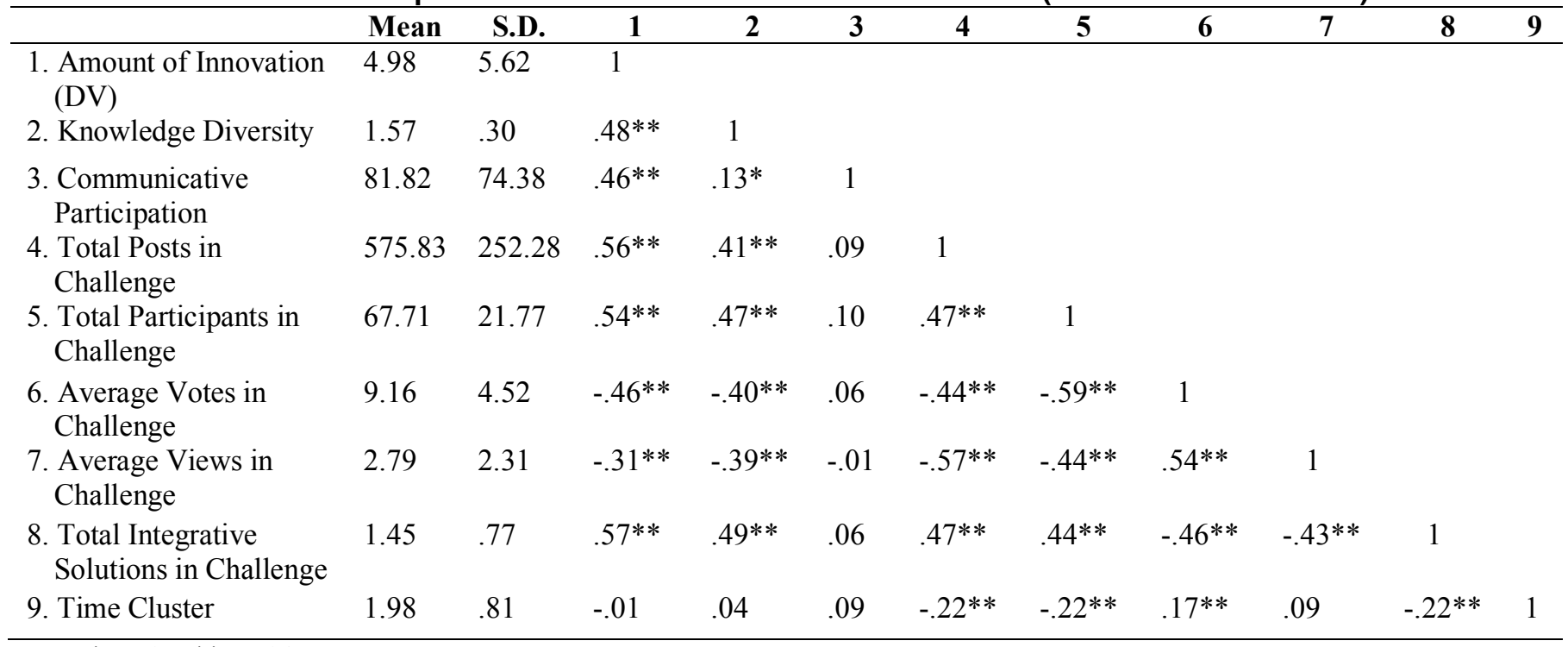
$* p<.05, * * p<.01$

Table 3. Descriptive Statistics and Zero-order Correlations (Serial Knowledge Integration)

\begin{tabular}{|c|c|c|c|c|c|c|c|c|c|c|c|}
\hline & Mean & S.D. & 1 & 2 & 3 & 4 & 5 & 6 & 7 & 8 & 9 \\
\hline $\begin{array}{l}\text { 1. Serial Knowledge } \\
\text { Integration (DV) }\end{array}$ & .39 & .49 & 1 & & & & & & & & \\
\hline 2. Knowledge Diversity & 1.57 & .30 & $-.40^{*}$ & 1 & & & & & & & \\
\hline $\begin{array}{l}\text { 3. Communicative } \\
\text { Participation }\end{array}$ & 81.82 & 74.38 & $.40 * *$ & $.13 *$ & 1 & & & & & & \\
\hline $\begin{array}{l}\text { 4. Total Posts in } \\
\text { Challenge }\end{array}$ & $\begin{array}{l}575.8 \\
3\end{array}$ & 252.28 & $-.30 * *$ & $.41 * *$ & .09 & 1 & & & & & \\
\hline $\begin{array}{l}\text { 5. Total Participants in } \\
\text { Challenge }\end{array}$ & 67.71 & 21.77 & $-.29 * *$ & $.47 * *$ & .10 & $.47 * *$ & 1 & & & & \\
\hline $\begin{array}{l}\text { 6. Average Votes in } \\
\text { Challenge }\end{array}$ & 9.16 & 4.52 & $.15^{*}$ & $-.40 * *$ & .06 & $-.44 * *$ & $-.59 * *$ & 1 & & & \\
\hline $\begin{array}{l}\text { 7. Average Views in } \\
\text { Challenge }\end{array}$ & 2.79 & 2.31 & $.23 * *$ & $-.39 * *$ & -.01 & $-.57 * *$ & $-.44 * *$ & $.54 * *$ & 1 & & \\
\hline $\begin{array}{l}\text { 8. Total Integrative } \\
\text { Solutions in Challenge }\end{array}$ & 1.45 & .77 & $-.29 * *$ & $.49 * *$ & .06 & $.47 * *$ & $.44 * *$ & $-.46^{* *}$ & $-.43 * *$ & 1 & \\
\hline 9. Time Cluster & 1.98 & .81 & $-.25 * *$ & .04 & $-.40 * *$ & $-.22 * *$ & $-.22 * *$ & $.17 * *$ & .09 & $-.22 * *$ & 1 \\
\hline
\end{tabular}

$$
{ }^{*} p<.05, * * p<.01
$$


3.2.2. Independent Variables. Knowledge diversity is one of the major independent variables, and it was calculated by considering the aforementioned six non-solution types of knowledge contribution $(\mathrm{M}=1.57, \mathrm{SD}=0.30)$ occurring prior to each post. Following Malhotra and Majchrzak [59], this study employed Blau's diversity index which mathematically captures both population diversity and qualitative variation $(i=1, \mathrm{n}=6)$. To avoid double counting, for each contributor's subsequent integrative solutions, only the posts occurring after his or her first integrative solution were used for calculating knowledge diversity.

Communicative participation of online crowd members is another major independent variable in this study $(\mathrm{M}=81.82, \mathrm{SD}=74.38)$, describing a member's activeness in online crowdsourcing. It was measured as a crowd member's total amount of communicative activities, namely, posting, voting, and viewing. In other words, this value was obtained by taking the sum of the numbers of posts, votes and views that a crowd member contributed.

3.2.3. Control Variables. Several control variables were included when constructing statistical models. First, for each crowdsourcing innovation challenge, the total number of involved participants $(\mathrm{M}=67.71, \mathrm{SD}=21.77)$ and the total number of posts $(\mathrm{M}=575.83, \mathrm{SD}=252.28)$ were calculated, based on a consideration of possible effects of group think [60, 61]. Moreover, the average numbers of votes $(M=9.16$, $\mathrm{SD}=4.51)$, knowledge integrations $(\mathrm{M}=1.45, \mathrm{SD}=0.77)$, and views $(\mathrm{M}=2.79, \mathrm{SD}=2.31)$ within each challenge were included in statistical models as well, in order to control for possible inflation effect caused by the qualitative uniqueness of the challenges $[62,63]$. Finally, the timing of all contributed posts was considered to control for possible temporal effects [64]. Using k-means clustering analysis with Matlab, the timestamps of all posts were grouped into three clusters so that each post belonged to a unique phase coded as 1,2 and 3, respectively.

\subsection{Data Analysis}

To test the hypotheses about serial knowledge integration, this study employed multinomial regression to build the statistical model. For hypotheses about the amount of innovation, this study employed generalized linear modeling to construct the regression model. In order to rule out a potential issue of multi-collinearity, variance inflation factors (VIFs) were checked before model construction, and results indicated that multi-collinearity was not an issue [65] in this study. Descriptive statistics and zero-order correlations are presented in Table 2 and Table 3.

\section{Results}

Statistical results from hypotheses testing are summarized in Table 4 and Table 5. Hypothesis 1 was supported $(\beta=1.19, p<0.01)$, suggesting that being exposed to diverse knowledge facilitates crowdsourcing participants' contribution of more innovative solutions in response to open challenges. Nevertheless, the second hypothesis was rejected, indicating that knowledge diversity is unable to predict the emergence of serial knowledge integration in crowdsourcing.

With regard to the effects of crowd members' communicative participation, $\mathrm{H} 3$ was supported $(\beta=$ $0.10, p<0.001)$, presenting that when participants exhibit a higher level of communicative participation in online crowdsourcing, they are able to produce more innovative solutions. In alignment with this reasoning, $\mathrm{H} 4$ was supported $(\beta=0.09, p<0.001)$ by the data as well, demonstrating that a higher level of communicative participation can give rise to a higher likelihood that serial knowledge integration emerges from crowdsourcing innovation challenges.

Table 4. Effects on Amount of Innovation

\begin{tabular}{|c|c|c|}
\hline \multirow{4}{*}{ (Intercept) } & \multicolumn{2}{|c|}{ Amount of Innovation } \\
\hline & Baseline Model & Full Model \\
\hline & -0.85 & -0.82 \\
\hline & $(0.78)$ & $(0.80)$ \\
\hline \multirow{2}{*}{$\begin{array}{l}\text { Total Posts in } \\
\text { Challenge }\end{array}$} & 0.01 & 0.01 \\
\hline & $(0.01)$ & $(0.01)$ \\
\hline \multirow{2}{*}{$\begin{array}{l}\text { Total Participants in } \\
\text { Challenge }\end{array}$} & -0.01 & -0.02 \\
\hline & $(0.03)$ & $(0.02)$ \\
\hline \multirow{2}{*}{$\begin{array}{l}\text { Average Votes in } \\
\text { Challenge }\end{array}$} & $-0.15 * *$ & $-0.22 * * *$ \\
\hline & $(0.05)$ & $(0.05)$ \\
\hline \multirow{2}{*}{$\begin{array}{l}\text { Average Integrative } \\
\text { Solutions in } \\
\text { Challenge }\end{array}$} & 0.27 & -0.25 \\
\hline & $(1.01)$ & $(1.02)$ \\
\hline \multirow{2}{*}{$\begin{array}{l}\text { Average Views in } \\
\text { Challenge }\end{array}$} & $0.14 *$ & 0.07 \\
\hline & $(0.06)$ & $(0.06)$ \\
\hline \multirow[t]{2}{*}{ Time Cluster } & $0.19^{* * *}$ & 0.01 \\
\hline & $(0.04)$ & $(0.04)$ \\
\hline \multirow{2}{*}{\multicolumn{2}{|c|}{$\begin{array}{l}\text { Knowledge } \\
\text { Diversity }\end{array}$}} & $1.19 * *$ \\
\hline & & $(0.46)$ \\
\hline \multirow{2}{*}{\multicolumn{2}{|c|}{$\begin{array}{l}\text { Communicative } \\
\text { Participation }\end{array}$}} & $0.10^{* * *}$ \\
\hline & & $(0.01)$ \\
\hline
\end{tabular}




\begin{tabular}{lrr}
\hline AICc & 1411.70 & 900.19 \\
BIC & 1435.65 & 930.81 \\
\hline${ }^{*} p<.05, *^{* *}<<.01, *^{* * *} p<.001$ &
\end{tabular}

Table 5. Effects on Serial Knowledge Integration

\begin{tabular}{lll}
\hline & \multicolumn{2}{l}{ Serial Knowledge Integration } \\
\cline { 2 - 3 } (Intercept) & -0.67 & -2.68 \\
& $(1.29)$ & $(2.36)$ \\
Total Posts in & 0.01 & 0.02 \\
Challenge & $(0.01)$ & $(0.01)$ \\
Total Participants & -0.05 & -0.06 \\
in Challenge & $(0.03)$ & $(0.04)$ \\
Average Votes in & 0.12 & -0.05 \\
Challenge & $(0.07)$ & $(0.14)$ \\
Average Integrative & -0.65 & -4.92 \\
Solutions in & $(1.60)$ & $(3.21)$ \\
Challenge & $-0.27^{*}$ & $-0.86^{* *}$ \\
Average Views in & $(0.11)$ & $(0.32)$ \\
Challenge & 0.43 & -0.02 \\
Time Cluster & $(0.23)$ & $(0.36)$ \\
& & -0.86 \\
Knowledge & & $(0.90)$ \\
Diversity & & $0.09^{* * *}$ \\
Communicative & & $(0.02)$ \\
Participation & & 118.48 \\
-2 Log Likelihood & 213.19 & \\
\hline$* 0.05, * * 01, * * *<.001$ & \\
\hline
\end{tabular}

${ }^{*} p<.05, * * p<.01, * * * p<.001$

\section{Discussion and Conclusion}

Examining online crowds' collaborative response to open innovation challenges, this study unpacks the effects of knowledge diversity and communicative participation on innovation and serial knowledge integration. The findings are twofold. First, this study shows that crowd members' diverse knowledge and communicative participation enable the crowd to generate an increasing amount of innovation in crowdsourcing. Second, given the critical role played by knowledge integration, the present study demonstrates the mechanism underlying crowd members' continuous contribution of knowledge integration, thus providing insights into making crowdsourced open innovation productive and sustainable.

Findings of this research shed light on open innovation. Innovation emerges from a dynamic knowledge management system in which knowledge contributors are allowed to constantly reconsider and reuse prior diverse knowledge [6,20,34,37-39,66]. When crowd members are exposed to heterogeneous domains of knowledge, they are better able to perceive the problem or the task from different angles and hence propose unconventional solutions. Further, by actively posting, viewing and voting, crowd members exchange thoughts, elaborate on rationales, raise questions, express disagreements, and collectively strike a balance through deliberate reasoning. As communicative participation facilitates the construction of mutual understanding, crowd members involved in such activities tend to be more cognitively capable of understanding different viewpoints and thus finding an optimal solution that is unique and creative $[50-52,56]$. Therefore, crowd scientists who seek for innovation should endeavor to implement systems that can encourage the crowd to make their diverse knowledge explicit as well as maintain a high level of communicative participation in crowdsourcing.

This study also provides implications for crowdbased knowledge management by demonstrating the importance of communicative participation in generating serial knowledge integration. Throughout the open innovation challenge, communicative participation helps crowd members overcome obstacles such as social unfamiliarity and membership fluidity [67-71], so that members are able to constantly synthesize others' various knowledge and thus to maintain the production of integrative solutions. However, the hypothesized effect of knowledge diversity on serial knowledge integration failed to receive support in this study. One possible reason could be that knowledge diversity results in cognitive overload and hence crowd members may find it difficult to reduce possible ambiguity or to fully absorb others' diverse knowledge [72-74], thus are unable to integrate others' shared knowledge into their own thinking. As such, decision makers who consider adopting crowdsourcing to harvest integrative solutions should be attentive to a possible overload of diverse knowledge and should design innovation challenges that encourage crowd members' communicative participation while minimizing the difficulty of cognitive knowledge processing for the members.

While this study provides theoretical and practical implications for crowdsourcing and innovation research, there are still a number of open issues it did not address. First, this research employed one single 
crowdsourcing platform instead of examining the possible impacts of various platforms. Further work should fill in this research gap. In addition, future studies should explore possible effects of topic distinction on crowd-sourced open innovation, as the effects remain unclear in the present research. Finally, in future research, larger-size online crowds should be recruited so that a greater number of posts generated in collaborative interactions can benefit advanced analyses.

\section{References}

[1] Chesbrough, H. (2006), Open innovation: The new imperative for creating and profiting from technology. Harvard Business Press.

[2] Leimeister, J. M., Huber, M., Bretschneider, U. and Krcmar, H. (2009), "Leveraging crowdsourcing: activationsupporting components for IT-based ideas competition", Journal of Management Information Systems, 26(1), pp.197224.

[3] Surowiecki, J. (2005), The Wisdom of the Crowds: Why the Many are Smarter Than the Few and How Collective Wisdom Shapes Business, Economics, Societies and Nations. NY: Doubleday.

[4] Afuah, A. and Tucci, C. L. (2012), "Crowdsourcing as a Solution to Distant Search", Academy of Management Review, 37(3), pp.355-375.

[5] Buchanan, R. (1992), "Wicked problems in design thinking", Design Issues, 8(2), pp.5-21.

[6] Harvey, S. (2014), "Creative synthesis: Exploring the process of extraordinary group creativity", Academy of Management Review, 39(3), pp.324-343.

[7] Pacanowsky, M. (1995), "Team tools for wicked problems", Organizational Dynamics, 23(3), pp.36-51.

[8] Malhotra, A. and Majchrzak, A. (2014), "Managing crowds in innovation challenges", California Management Review, 56(4), pp.103-123.

[9] Schenk, E. and Guittard, C. (2011), "Towards a characterization of crowdsourcing practices", Journal of Innovation Economics \& Management, 1, pp.93-107.

[10] Howe, J. (2006), "The rise of crowdsourcing", Wired Magazine, 14(6), pp.1-4.

[11] Brabham, D. C. (2010), "Moving the crowd at Threadless: Motivations for participation in a crowdsourcing application", Information, Communication \& Society, 13(8), pp.1122-1145.

[12] Chesbrough, H. W. (2003), "A better way to innovate". Harvard Business Review, 81(7), pp. 12-13.

[13] von Krogh, G., and Spaeth, S. (2007), "The open source software phenomenon: Characteristics that promote research", The Journal of Strategic Information Systems, 16(3), pp.236-253.

[14] Christensen, J. F., Olesen, M. H. and Kjær, J. S. (2005), "The industrial dynamics of Open Innovation-Evidence from the transformation of consumer electronics", Research Policy, 34(10), pp.1533-1549.
[15] Dodgson, M., Gann, D. and Salter, A. J. (2005). Think, play, do: Technology, innovation, and organization. Oxford University Press, UK.

[16] Dahlander, L. and Gann, D. M. (2010). "How open is innovation?", Research Policy, 39(6), pp.699-709.

[17] Gassmann, O. (2006). "Opening up the innovation process: towards an agenda”, R\&D Management, 36(3), pp.223-228.

[18] Gassmann, O. and Enkel, E. (2004), "Towards a theory of open innovation: three core process archetypes". R\&D Management Conference (RADMA), Lissabon.

[19] Boh, W.F., Ren, Y., Kiesler, S. and Bussjaeger, R. (2007), "Expertise and collaboration in the geographically dispersed organization”, Organization Science, 18(4), pp.595-612.

[20] Boudreau, K.J., Lacetera, N. and Lakhani, K.R. (2011), "Incentives and problem uncertainty in innovation contests: An empirical analysis", Management Science, 57(5), pp.843. [21] Majchrzak, A., Cooper, L.P. and Neece, O.E. (2004), "Knowledge reuse for innovation", Management science, 50(2), pp.174-188.

[22] Terwiesch, C. and Xu, Y. (2008), "Innovation contests, open innovation, and multiagent problem solving", Management Science, 54(9), pp.1529-1543.

[23] Zheng, H., Li, D. and Hou, W. (2011), "Task design, motivation, and participation in crowdsourcing contests", International Journal of Electronic Commerce, 15(4), pp.5788.

[24] Alavi, M. and Tiwana, A. (2002), "Knowledge integration in virtual teams: The potential role of KMS", Journal of the American Society for Information Science and Technology, 53(12), pp.1029-1037.

[25] Ciborra, C. U. and Andreu, R. (2001), "Sharing knowledge across boundaries", Journal of Information Technology, 16(2), pp.73-81.

[26] Darr, E. D., Argote, L. and Epple, D. (1995), "The Acquisition, Transfer, and Depreciation of Knowledge in Service Organizations: Productivity in Franchises", Management Science, 41(11), pp.1750-1762.

[27] Majchrzak, A., More, P. H. and Faraj, S. (2012), "Transcending knowledge differences in cross-functional teams", Organization Science, 23(4), pp.951-970.

[28] Faraj, S., Jarvenpaa, S. L. and Majchrzak, A. (2011), "Knowledge collaboration in online communities", Organization Science, 22(5), pp.1224-1239.

[29] Majchrzak, A. and Malhotra, A. (2016), "Effect of knowledge-sharing trajectories on innovative outcomes in temporary online crowds", Information Systems Research, 27(4), pp.685-703.

[30] Bingham, A., and Spradlin, D. (2011), The open innovation marketplace: creating value in the challenge driven enterprise. FT press.

[31] Dahan, E. and Mendelson, H. (2001), "An extremevalue model of concept testing", Management Science, 47(1), pp.102-116.

[32] Schemmann, B., Herrmann, A. M., Chappin, M. M. and Heimeriks, G. J. (2016), "Crowdsourcing ideas: Involving ordinary users in the ideation phase of new product development", Research Policy, 45(6), pp.1145-1154. 
[33] Terwiesch, C. and Ulrich, K. T. (2009), Innovation tournaments: Creating and selecting exceptional opportunities. Harvard Business Press.

[34] Brabham, D. C. (2013), Crowdsourcing. John Wiley \& Sons, Inc.

[35] Buecheler, T., Sieg, J. H., Füchslin, R. M. and Pfeifer, R. (2010), "Crowdsourcing, Open Innovation and Collective Intelligence in the Scientific Method-A Research Agenda and Operational Framework", The 12th International Conference on the Synthesis and Simulation of Living Systems, MIT Press, pp. 679-686.

[36] Erickson, L., Petrick, I. and Trauth, E. (2012), "Hanging with the right crowd: Matching crowdsourcing need to crowd characteristics", Proceedings of the $18^{\text {th }}$ Americas Conference on Information Systems, pp.1-9.

[37] Boudreau, K. J. (2012), "Let a thousand flowers bloom? An early look at large numbers of software app developers and patterns of innovation", Organization Science, 23(5), pp.1409-1427.

[38] Jeppesen, L. B. and Lakhani, K. R. (2010), "Marginality and problem-solving effectiveness in broadcast search", Organization Science, 21(5), pp.1016-1033.

[39] Poetz, M. K. and Schreier, M. (2012), "The value of crowdsourcing: can users really compete with professionals in generating new product ideas?", Journal of Product Innovation Management, 29(2), pp.245-256

[40] Kelley, T. (2007), The art of innovation: Lessons in creativity from IDEO, America's leading design firm. Crown Business.

[41] Cronin, M.A. and Weingart, L.R. (2007), "Representational gaps, information processing, and conflict in functionally diverse teams", Academy of Management Review, 32(3), pp. 761-773.

[42] Kellogg, K. C., Orlikowski, W. J. and Yates, J. (2006), "Life in the trading zone: Structuring coordination across boundaries in postbureaucratic organizations", Organization Science, 17(1), pp.22-44.

[43] Nandhakumar, J., Panourgias, N. S. and Scarbrough, H. (2013), "From knowing it to "getting it": Envisioning practices in computer games development", Information Systems Research, 24(4), pp.933-955.

[44] Burke, M. and Kraut, R. E. (2014), "Growing closer on Facebook: changes in tie strength through social network site use", Proceedings of the SIGCHI Conference on Human Factors in Computing Systems, ACM, pp.4187-4196.

[45] Wagner, D., Vollmar, G. and Wagner, H. T. (2014), "The impact of information technology on knowledge creation: An affordance approach to social media", Journal of Enterprise Information Management, 27(1), pp.31-44.

[46] Armbrecht Jr, F. R., Chapas, R. B., Chappelow, C. C., Farris, G. F., Friga, P. N., Hartz, C. A., McIlvaine, M.E., Postle, S.R., and Whitwell, G. E. (2001), "Knowledge management in research and development", Research Technology Management, 44(4), pp.28-48.

[47] Grant, A.M. and Berry, J.W. (2011), "The necessity of others is the mother of invention: Intrinsic and prosocial motivations, perspective taking, and creativity", Academy of Management Journal, 54(1), pp.73-96.

[48] Nonaka, I. and Von Krogh, G. (2009), "PerspectiveTacit knowledge and knowledge conversion: Controversy and advancement in organizational knowledge creation theory", Organization Science, 20(3), pp.635-652.

[49] Marshall, N. and Rollinson, J. (2004), "Maybe Bacon had a point: The politics of interpretation in collective sensemaking", British Journal of Management, 15, pp.71-86.

[50] Amabile, T.M. (1988), "A model of creativity and innovation in organizations", Research in Organizational Behavior, 10(1), pp.123-167.

[51] Hargadon, A. and Sutton, R. I. (1997), "Technology brokering and innovation in a product development firm", Administrative Science Quarterly, 42(4), pp.716-749.

[52] Van de Ven, A. H. (1986), "Central problems in the management of innovation”, Management Science, 32(5), pp.590-607.

[53] Drazin, R., Glynn, M. A. and Kazanjian, R. K. (1999), "Multilevel theorizing about creativity in organizations: A sensemaking perspective", Academy of Management Review, 24(2), pp.286-307.

[54] Oldham, G. R. and Cummings, A. (1996), "Employee creativity: Personal and contextual factors at work", Academy of Management Journal, 39(3), pp.607-634.

[55] Woodman, R. W., Sawyer, J. E. and Griffin, R. W. (1993), "Toward a theory of organizational creativity", Academy of Management Review,18(2), pp.293. [56] Hossain, M., and Islam, K. Z. (2015), "Ideation through online open innovation platform: dell IdeaStorm", Journal of the Knowledge Economy, 6(3), pp.611-624.

[57] Parent, M., Gallupe, R. B., Salisbury, W. D. and Handelman, J. M. (2000), "Knowledge creation in focus groups: can group technologies help?", Information \& Management, 38(1), pp.47-58.

[58] Bechky, B. A. (2003), "Sharing meaning across occupational communities: The transformation of understanding on a production floor", Organization Science, 14(3), pp.312-330.

[59] Malhotra, A. and Majchrzak, A. (2019). "Greater associative knowledge variety in crowdsourcing platforms leads to generation of novel solutions by crowds", Journal of Knowledge Management, 23(8), pp.1628-1651.

[60] Janis, I. L. (1972), Victims of groupthink: A psychological study of foreign-policy decisions and fiascoes. Oxford, England: Houghton Mifflin.

[61] Wenger, E., McDermott, R. A. and Snyder, W. (2002), Cultivating communities of practice: A guide to managing knowledge. Harvard Business Press.

[62] Wang, Y. and Fesenmaier, D. R. (2003), “Assessing motivation of contribution in online communities: An empirical investigation of an online travel community", Electronic Markets, 13(1), pp.33-45.

[63] Zhang, D., Zhang, F., Lin, M. and Du, H. S. (2017), "Knowledge sharing among innovative customers in a virtual innovation community: The roles of psychological capital, material reward and reciprocal relationship", Online Information Review, 41(5), pp.691-709.

[64] Heo, M. and Toomey, N. (2015), "Motivating continued knowledge sharing in crowdsourcing: The impact of different types of visual feedback", Online Information Review, 39(6), pp.795-811.

[65] Kutner, M. H., Nachtsheim, C. and Neter, J. (2004), Applied linear regression models. McGrawHill/Irwin. 
[66] Razmerita, L., Kirchner, K. and Sudzina, F. (2009), "Personal knowledge management: The role of Web 2.0 tools for managing knowledge at individual and organisational levels", Online Information Review, 33(6), pp.1021-1039.

[67] Bolisani, E. and Scarso, E. (1999), "Information technology management: a knowledge-based perspective", Technovation,19(4), pp.209-217.

[68] Carlile, P. R. (2004), "Transferring, translating, and transforming: An integrative framework for managing knowledge across boundaries", Organization Science, 15(5), pp.555-568.

[69] Hislop, D. (2002), "Mission impossible? Communicating and sharing knowledge via information technology", Journal of Information Technology, 17(3), pp.165-177.
[70] Hoever, I. J., Van Knippenberg, D., van Ginkel, W. P. and Barkema, H. G. (2012), "Fostering team creativity: perspective taking as key to unlocking diversity's potential", Journal of Applied Psychology, 97(5), pp.982.

[71] Krauss, R. M. and Fussell, S. R. (1991), "Perspectivetaking in communication: Representations of others' knowledge in reference", Social Cognition, 9(1), pp.2-24.

[72] Fleming, L. (2001). "Recombinant uncertainty in technological search", Management Science, 47(1), pp.117.

[73] Fleming, L. and Waguespack, D. M. (2007). "Brokerage, boundary spanning, and leadership in open innovation communities", Organization Science, 18(2), pp. 165-180.

[74] Kirsh, D. (2000), "A few thoughts on cognitive overload”, Intellectica, 1(30), pp. 19-51. 